\title{
19. The Contemporary Russian Cosmopolitans
}

\author{
Anna Ljunggren \\ Slavic Languages, Stockholm University
}

In an entry from his journal Diary of a Writer from I873, Dostoevsky offers readers some memories of his contemporary, the writer Alexander Herzen, who had died in exile in Paris three years earlier:

He was a product of our aristocracy, gentilhomme russe et citoyen $d u$ monde above all, a type that appeared only in Russia and which could appear only in Russia. Herzen did not emigrate and did not lay the foundation for other Russian emigrés; no, he was simply born an emigré. They all, those people like him, were just born emigrés, even though the majority of them never left Russia. In one hundred and fifty years of the life of the Russian gentry that preceded him, with only a few exceptions, the last roots rotted and the last links with the Russian soil and the Russian truth were shaken loose. ${ }^{\text {I }}$

Dostoevsky depicts the Russian cosmopolitan with irony and venom; nonetheless his exposition grasps some significant traits of this cultural phenomenon, which "could appear only in Russia" in the post-Petrine period of its history ("one hundred and fifty years of the life of the Russian gentry" had passed by

I Fyodor Dostoevsky, “Old People”, A Writer's Diary vol. I I873-76, trans. Kenneth Lantz. With an Introductory study by Gary Saul Morson (Evanson, Ill.: Northwestern University Press, I994), I 26.

How to cite this book chapter:

Ljunggren, Anna. "The Contemporary Russian Cosmopolitans". In World Literatures: Exploring the Cosmopolitan-Vernacular Exchange, edited by Stefan Helgesson, Annika Mörte Alling, Yvonne Lindqvist, and Helena Wulff, 2 I I-228. Stockholm: Stockholm University Press, 20I8. DOI: https:// doi.org/IO.I6993/bat.s. License: CC-BY. 
the time Dostoevsky wrote the piece). Dostoevsky's observations are built in two steps. First, he establishes a connection between exile and the internal westernisation of Russia, and secondly, a connection between cosmopolitanism and westernisation. In other words, Russian cosmopolitanism is not all-embracing: it has been historically "wedded" to the west, and has treated Europe as a metaphor for enlightenment and universalism. ${ }^{2}$ Its opposite is "Russia as Asia", which stands for Russia as unenlightened, backward, despotic - that is, as vernacular in a bad sense. The opposition between the internalised west and authentic and archaic Russianness constitutes what is regarded in semiotics as the "inner dichotomy" specific to Russian culture. ${ }^{3}$ The tension between these opposites has taken the form of literary and philosophical disputes, clashes between cultural and political doctrines and ideas (as in Dostoevsky's times between slavophiles and westernisers). It is important to stress that these two aspects have coexisted historically and that their interaction has defined the dynamics of Russian culture for centuries, including the Soviet and Post-Soviet periods. The strong connection between cosmopolitanism and interior westernisation of Russian culture is what distinguishes the Russian cosmopolitan discourse from that of the present-day west, where cosmopolitanism is strongly linked to the postcolonial condition and is fuelled by its inequalities.

While the Soviet Union was culturally isolated from the west, it created its own version of cosmopolitanism. The philosopher,

${ }^{2}$ Boris Uspensky, "Europe as Metaphor and Metonymy (in Relation to the History of Russia)", in Boris Uspensky and Viktor Zhivov, "Tsar and God" and Other Essays in Russian Cultural Semiotics (Boston: Academic Studies Press, 2012), I 75-90.

3 Lotman opposes the "binary" culture of Russia to the "ternary" cultures of Western Europe: Juri Lotman, Culture and Explosion. Semiotics, Communication and Cognition, ed. Marina Grishakova (Berlin-New York: De Gruyter Mouton, 2009), I66-I72; Jurii Lotman and Boris Uspensky,"Binary Models in the Dynamics of Russian Culture (to the End of the Eighteenth Century)", in Jurii Lotman and Boris Uspenskii, The Semiotics of Russian Cultural History, ed. Alexander D. Nakhimovsky and Alice Stone Nakhimovsky (Ithaca and London: Cornell University Press, I985), 30-67. 
art critic and curator Boris Groys argues that the USSR, in its endeavour to radically modernise cultural politics in "one isolated country" (to use Lenin's words about the October Revolution), formulated a doctrine of "Communist internationalism" that can be seen as a prefiguration of contemporary globalisation in the wide sense. ${ }^{4}$ During the later period, Soviet "internationalism" became centripetal, primarily embracing the nationalities of the USSR led by Russia, and also including the countries of the socialist bloc. When the project to create "an isolated future" collapsed, Russia had to attempt to return to its pre-Soviet roots. ${ }^{5}$

The isolation of the USSR was not absolute. During the late I960s and '70s, the question of emigration became a burning issue both culturally and politically. Even though "the third wave" of Russian emigration to the west was extremely restricted, its impact on cultural and intellectual life was overwhelming. Whether "to leave or to stay" was discussed behind closed doors in the kitchens of the Moscow and Leningrad intelligentsia. This dilemma prompted a debate about the significance of one's native environment for creative work, and it was probably the most recent cultural expression of the very dichotomy that the semioticians Lotman and Uspensky described around this time.

The American anthropologist Alexei Yurchak has spoken about the "imaginary West" as a collective image invested with metaphysical significance in the late Soviet period. ${ }^{6}$ It was an imaginary "elsewhere" that, using M. Foucault's term, one could call a late Soviet "heterotopia". 7 It was a cosmopolitan aesthetic utopia with

${ }^{4}$ Boris Groys, "Zurück aus der Zukunft: Kunst aus Ost und West”, in Zurück aus der Zukunft: osteuropäische Kulturen im Zeitalter des Postkommunismus, ed. Boris Groys et al. (Frankfurt am Main, 2005), $422-423$.

5 Groys, 423.

${ }^{6}$ Alexei Yurchak, Everything Was Forever, Until It Was No More: The Last Soviet Generation (Princeton, NJ: Princeton University Press, 2005), I 26-207.

7 Michel Foucault, "Des espaces autres", Empan 54 (2004/2): I2-I9, accessed I6 March 20I7, https://www.cairn.info/revue-empan-2004-2page-I $2 . h$ htm. 
metaphysical overtones, constructed on the remains of Russian modernism and its visions.

The prevalence of aesthetics in this "imaginary West" can in fact explain why, as the prominent poet Olga Sedakova put it, the real encounter with the west during Perestroika turned out to be a disappointment ("we did not expect everyday life, but an aesthetic, moral, philosophical Europe"). ${ }^{8}$ This disillusionment has recently led to the Russian intelligentsia's partial withdrawal from "Occidentalism", characteristic of the unofficial late-Soviet culture.

\section{Exile Literature or Transcultural Literature?}

When two key figures of the unofficial culture of the I970s - first Brodsky and then Solzhenitsyn - were expelled from the USSR, the centrifugal trend of the unofficial part of Soviet culture gathered momentum. What followed upon their expulsion revealed the fundamental differences in cultural choices that could be made in exile. While Solzhenitsyn worked and saw himself as a Russian writer and political thinker in exile, Brodsky took a step into Anglo-American literature, both as a prose writer and - although not always as successfully - as a poet. It can be argued that exile is insufficient as a term covering diverging cultural paths. ${ }^{9}$ It can also be argued that these choices and types of cultural orientation

${ }^{8}$ Olga Sedakova, A poetry reading and discussion at the Department of Slavic Languages and Literatures (Stockholm University), 23 April 20I2, accessed I6 March 20I7, https:/www.youtube.com/ watch?v=FrL 7 wp-uwFM.

9 The terms "exilic", "diasporic" and "transnational" are used as synonyms in Azade Seyhan, Writing Outside the Nation (Princeton, NJ, and Oxford: Princeton University Press, 200I), I I. In the Russian cultural context, further distinction is required. See also Eva Hausbacher's argument for a reconceptualisation of "exile": Eva Hausbacher, Poetik der Migration. Transnationale Schreibweisen in der zeitgenössischen russischen Literatur (Tübingen, 2009), 9-18. See also Adrian Wanner, Fictions of a New Translingual Diaspora (Evanston, IL: Northwestern University Press, 2OII), 4 . 
are predetermined by a preexisting dichotomy within Russian culture.

Chronologically, generations of the Russian emigration in the twentieth century are counted in "waves": Nabokov belongs to the first, which stretches in time and overlaps with the third wave, Brodsky to the third, and Makine and Shishkin to the fourth.

Nabokov stopped being "a Russian exile writer" when he moved to the United States in May I940, abandoning his pseudonym Sirin and leaving his last novel written in Russian, Solus Rex, unfinished. Brodsky defied the fact that he was banned, which for him meant to thwart the limitations imposed by the official Soviet patriotism and its prohibitions. In the speech "The Condition We Call Exile" ( I 988) he speaks instead of its "very strong, very clear metaphysical dimension". ${ }^{\text {г }}$

The political climate of today allows for much more flexibility. Writers of the younger generation, such as Mikhail Shishkin, who resides in Switzerland and writes in Russian, simply do not find the question about his being or not being an exile writer relevant. Andreï Makine (also writing under the pseudonym Gabriel Osmonde) has taken a different path; he chose to write exclusively in French and has recently been elected into the French Academy, which consecrated him as a French writer.

The term "transcultural" seems to be the most appropriate to describe complex mobility in the contemporary world. ${ }^{\text {II }}$ It stresses the dynamics of transition between two cultural spaces. If we

ro Joseph Brodsky, "The Condition We Call Exile”, New York Review of Books, 2I January I988, accessed I7 March 20I7, http://www.bisla.sk/ english/wp-content/uploads/20I 5/oI/Joseph-Brodsky-The-ConditionWe-Call-Exile.pdf.

II The term "transcultural" used here, is synonymous to "transnational" or "migrant", all in circulation at present. One reason why "transcultural" is preferable in the Russian context is that the Russian culture excedes the limits of Russia proper. Another is that it is more congruent with the question of poetics. One more important consideration here is how the authors define themselves: one should exercise caution with respect to terminology in order to avoid labels that might be rejected by authors themselves. In this respect also, because of its neutrality, "transcultural" seems to be preferable. 
admit that transcultural literature has vernacular "difference" as a prerequisite, it becomes possible to see its similarity with anthropological discourse, which, according to French anthropologist Marc Augé, is based on difference and universality at the same time. ${ }^{\mathrm{I2}}$ Even Appadurai defines contemporary cultural dynamics in terms of "tension between cultural homogenization and cultural heterogenization". ${ }^{\text {I3 }}$ Transcultural literature mediates the native experience into a new cultural context, often by means of the language of this new cultural sphere. ${ }^{14}$

The process of mediation can be irreversible. One such trend was the "branding" of the Soviet Russian experience (Soviet exoticism) - as in Makine's novels, rejected in Russia for their "constructed" Russianness built on clichés. ${ }^{15}$ To the traditional Russian images, such as snow and steppes, some Soviet ones were added; on a larger scale, defined historical narratives of WWII or the Siege of Leningrad were introduced to the French reader as the background for a love story in Heaven and Earth of Jacques Dorme (La terre et le ciel de Jacques Dorme [2003]) and The Life of an Unknown Man (La vie d'un homme inconnu [2009]). One

I2 Marc Augé states that anthropology is based on a triple experience: plurality, difference ("alterité") and identity: Marc Augé, Pour une anthropologie des mondes contemporains (Paris: Aubier, I994), 8I. Augé describes a crisis of difference in a shrinking world of globalisation as a reduction of the cultural value of difference, which is no longer concept of invested with prestige of exoticism (8I). See also a discussion of the cosmopolitanism understood as openness to cultural diversity in David Damrosch, What is World Literature? (Princeton and Oxford: Princeton University Press, 2003), I 20-2I.

${ }^{13}$ Arjun Appadurai, "Disjuncture and Difference in the Global Cultural Economy", in Theory. Culture. Society, I990, accessed I7 March 20I7, http://www.arjunappadurai.org /articles/Appadurai Disjuncture_and _Difference_in_the_Global_Cultural_Economy.pdf.

${ }^{14}$ The deterritorialised vernacular becomes a sign in the complex cultural interactions of today. See the discussion of the semiotisation of "difference" in Homi K. Bhabba, "Cultural Diversity and Cultural Differences", accessed 2I March 20I7, http://monumenttotransformation.org/atlas-of-transformation/html/c/cultural-diversity/cultural-diversity-and-cultural-differences-homi-k-bhabha.html.

is Adrian Wanner speaks of "constructed Russianness for foreign consumption”: Wanner, Out of Russia, 3. 
may ask on which side of the communication between western Europe and Russia these clichés originated. It seems that they are a product of cultural interaction and are akin to translation, not from language to language, but in a broader sense, from culture to culture. This effect is comparable to the impact which an anticipated translation may have on a text, as described by Rebecca Walkowitz in her Born Translated. ${ }^{16}$ To draw an analogy with anthropology, it is as if a native would be telling an anthropologist his experience using the anthropologist's language and concepts. ${ }^{17}$

\section{Towards a Poetics of Transcultural Literatures: Chronotope and Genre}

Vladimir Nabokov, Joseph Brodsky, Andreï Makine and Mikhail Shishkin have the same mother tongue and country of origin, Russia. Their biographies share one fundamental feature displacement ${ }^{18}$ - and their work has been integrated into different host cultures: Anglo-American, French and Swiss-German. But are there common features in their writing, in spite of the differences, that can be called a poetics of transculturalism? The question of recurrent patterns is not a formal one. Rather, it concerns how transcultural writers represent, and thereby shape, the world. Research in this area is still limited, trying to catch up with a development that is unfolding before our eyes; yet the answer that the

${ }^{16}$ On "pre-emptive translation" see Rebecca Walkowitz, Born Translated. The Contemporary Novel in an Age of World Literature (New York: Columbia University Press, 20I 5), I I-I7.

${ }^{17}$ Adrian Wanner observes that a transcultural autobiography is frequently perceived as an authentic ethnographic document: Wanner, Out of Russia, ro.

I8 Eva Hausbacher includes "displacement" as a common denominator in her discussion of transcultural poetics. It seems, however, that this concept should be applied to authors' biographies, not to their texts (Hausbacher, Poetik der Migration, II-I2, I36-45). Adrian Wanner comments on "constructed Russianness for foreign consumption" (Wanner, Out of Russia, 3). Displacement is used as a term by Homi K. Bhabba in relation to transcultural experience (Homi K. Bhabha, The Location of Culture (New York: Routledge, I994), passim). 
few works that exist on the subject are pointing to, is "yes". ${ }^{19}$ This "yes", however, still requires both in-depth studies of individual authors as well as a comparative investigations on a wider scale. ${ }^{20}$ In the growing body of works on individual writers, there are only a few that aim to present an overview of the phenomenon. ${ }^{21}$

Two issues characteristic of transcultural writing will be presented below. Firstly, patterns of spatio-temporal organisation will be outlined on the basis of the works of the authors chosen for this study. Secondly, the issue of the re-use of traditional genres will be addressed in connection with the phenomenon of "translingual autobiography".

A discussion of the poetics of a prosaic text can be based on what Mikhail Bakhtin called a "chronotope". ${ }^{22}$ This notion represents the fusion of the categories of time and space into a "novelistic world". According to Bakhtin, both the type of protagonist and the genre of a text are related to its chronotope. The space of transcultural texts is frequently bipartite, being an instance of

I9 Eva Hausbacher's Poetik des Migration is a major contribution to the study of the poetics of Russian migrant literature; however, its scope is limited to contemporary writers of Russian extraction residing in Germany.

20 Alain Ausoni discusses common features in bilingual autobiographies independently from the writer's country of origin (Alain Ausoni, "En d'autres mots: écriture translingue et autobiographie", in L'Autobiographie entre autres. Écrire la vie aujourd'hui, ed. Fabien Arribert-Narce and Alain Ausoni (Oxford and Bern: Peter Lang, 2013), 63-84). Wanner discusses a number of translingual diasporic Russian authors independently of their adopted language as a single phenomenon (Wanner, Out of Russia, 3-1 8).

21 One can mention some works not focused on poetics which try to present a wide overview and discussion of the phenomenon, notably in Bhabha, Location of Culture; Steven Kellman, The Translingual Imagination (Lincoln and London: University of Nebraska Press, 2000); Transcultural Identities in Contemporary Literature, ed. Irene Gilsenan Nordin et al. (Amsterdam: Rodopi, 20I3); see also Yoon Sun, “The Postcolonial Novel and Diaspora", in The Cambridge Companion to the Postcolonial Novel, ed. Ato Quayson (Cambridge University Press, 20I 5), I33-5I.

${ }_{22}$ Mikhail Bakhtin, "Forms of Time and of the Chronotope in the Novel", The Dialogic Imagination: Four Essays, ed. Michael Holquist (Austin: University of Texas Press, 2008), 84-258. 
what Eva Hausbacher calls the "duplication" ("Duplizität") that permeates transcultural writing. ${ }^{23}$ Bipartite narratives can be created by means of a counterpoint technique or through a frame construction. Two countries, two cultures are here juxtaposed: Makine's stories oscillate between Paris and Siberia, Shishkin's between Moscow and Zurich.

Transition in space is related to shifts in time. Time can by divided into "now" and "before" following the pattern of "duplication". It can be both the time of retroactively related progression from old to new or a "dive" backwards in time, which Justine McConnell calls "kathabasis" in her study of South African literature. ${ }^{24}$ Makine's already mentioned The Life of an Unknown Man is constructed as a two-step "descent": first into the protagonist's personal past - to meet his old love in St Petersburg, and then a step further into the big national narrative of Russian history the siege of Leningrad during the Second World War.

The divided spaces are mediated by a protagonist who acts as a go-between: a traveller, a translator, or even a spy. Transition itself becomes the theme of transcultural texts, as in Brodsky's "Watermark" or Makine's The Life of an Unknown Man. The travels in these texts are connected to self-definition, or rather self-redefinition, and have overtones of initiation or rebirth. ${ }^{25}$

The difference between spaces can get neutralised in utopia: in Nabokov's Ada, his "most cosmopolitan and poetic novel", ${ }^{26}$ protagonists belonging to a trilingual family of Russian descent are placed on a planet called Antiterra, where Russian, French and American toponyms intermingle and even rhyme. Nabokov's utopia in Ada is cumulative: it not only brings together toponyms in three languages, but also anachronistically fuses the different time periods of one century. Gabriel Osmonde (Andreï Makine's

\footnotetext{
${ }_{23}$ Hausbacher, Poetik der Migration, I I7-I 8, I4 I.

${ }^{24}$ Justine McConnell, “Generation Telemachus: Dinaw Mengestu's How to Read the Air", in Ancient Greek Myth in World Fiction since I989, ed. Justine McConnell and Edith Hall (London: Bloomsbury, 2016), 225-37.

25 Ausoni, "En d'autres mots", 64, 73.

${ }_{26}$ Vladimir Nabokov, Strong Opinions (New York: Vintage International, I990), I77.
} 
pseudonym) situates the protagonist of his Alternaissance (20II), a Russian expatriate, in an experimental global community called the Diggers Foundation, whose centre is placed in the heterotopian "far away" of Australia.

It is the writing subject who creates continuity and bridges spatial and cultural gaps within "the third space" of the text itself. ${ }^{27}$ The transcultural text frequently comments upon itself and the theme of writing. At the same time, there is a tendency to shift from an ethnic space and substitute it with a textual "space", i.e. a book within the book or picture within the book (ekphrasis). As a consequence, transcultural writing is saturated with quotes; Nabokov's Ada is but one example.

Turning to the question of genres, one might say that transcultural prose has not developed its own new genres, but has instead modified canonical ones, adjusting them to its own purposes. It has been observed that a favoured genre of transcultural writing is the autobiography that treats a transition, a "metamorphosis" into a new culture; ${ }^{28}$ Makine compares the transition to a second literary language to a second birth. ${ }^{29}$ Translingual autobiographies differ from their native counterparts: they perform an act of recreation and rewriting of one's biography in the language of a new cultural sphere.

A frequently cited example is Nabokov's Conclusive Evidencel Speak, Memory (I95I), which was written in English, subsequently auto-translated into Russian under the title Drugie berega (1954) [Other Shores], and once again reappeared as Speak, Memory: An Autobiography Revisited (1966).30 The

${ }_{27}$ Bhabba speaks of "survival cultures" and foregrounds the functional, performative aspect of their texts: Bhabba, The Location of Culture, I72.

${ }_{28}$ See for example, Wanner, Out of Russia, ro.

29 Andreï Makine, Cette France qu'on oublie d'aimer (Paris: Flammarion, 2006), 6I.

30 Chapter Five of Speak, Memory, about the Nabokovs' Swiss-French governess, is the earliest part of the text preserved; it was written originally in French, signed Nabokoff-Sirine and published under the title "Mademoiselle O" in a quarterly Mesures 2 (P., I936). The literary journal had on its editorial board Jean Poulhan, Henri Michaux and Giuseppe Ungaretti; before the war, it had published a wide range of 
book ends with the Nabokov family's departure for America in May 1940. What remains unspoken in the retrospective narrative is the entirety of WWII: the gap in between distances Nabokov from Russia and western Europe, both distorted and bastardised in the course of history (as shown in his wartime dystopia, Bend Sinister). Nabokov places emphasis not on the loss but, conversely, on the continued atemporal existence of the past in memory and imagination - as in his Speak, Memory, or in the utopia of Ada, where "memory meets imagination halfway". ${ }^{3}$ What follows in this progression is Look at the Harlequins! (I974), where Nabokov creates a fictional parody of his autobiography (his mask) and tests further the border between autobiography and fiction. His protagonist is the author of Nabokov's own novels under recognisable titles: A Kingdom by the Sea for Lolita, Ardis for Ada etc. The theme of time is dominant in all these works.

Writing in two different languages triggers divergence between the Russian and English versions as they interact with two different literary contexts: together, they form one two-faced Januslike book, to use Georges Nivat's expression. ${ }^{32}$ Nabokov returns to Russian as a translator, previously having abandoned it as his literary language. As Elizabeth Klosty Beaujour comments, for the bilingual author, the pains of metamorphosis are those

authors, French and foreign in French translation. Among them were Paul Claudel, André Gide, Paul Eluard, Jules Supervielle, as well as James Joyce, T.S. Eliot, Stefan George, Franz Kafka, F. G. Lorca and J. L. Borges; among Russians it published Pushkin, Tolstoy, Dostoevsky, even the Archpriest Avvakum, as well as Nabokov's contemporaries, a Russian philosopher Lev Shestov and a Symbolist writer Aleksei Remizov.

${ }^{31}$ Nabokov's words refer to Van Veen, the protagonist of Ada: "Memory met imagination halfway in the hammock of his boyhood's dawns". Vladimir Nabokov, Ada or Ardor: A Family Chronicle (New York: Penguin Classics, 20II), 52.

32 Georges Nivat, "Speak, Memory", in Garland Companion to Vladimir Nabokov, ed. Vladimir Alexandrov (New York: Garland, I995), 677, 680-82. See also Jane Grayson, Nabokov Translated: A Comparison of Nabokov's Russian and English Prose (Oxford: Oxford University Press, I977). 
of self-translation ${ }^{33}$ Nabokov's later multilingual novel $A d a$ is indebted both linguistically and thematically to bilingual redactions of Speak, Memory.

Translingual autobiographies have an additional dimension: they are performative, i.e. they not only tell of the transition, but enact it. ${ }^{34} \mathrm{~A}$ comparison between Brodsky's autobiographical essay "Watermark" and Boris Pasternak's "Safe Conduct" (I929-I930) can help to uncover this dimension. The title "Watermark", which is directly related to Venice, also has a second meaning, that of a sign of authenticity, which echoes the title of Pasternak's essay. "Safe Conduct", dedicated to the memory of Rainer Maria Rilke, contains chapters about Pasternak's student year in Marburg and a trip to Venice, and is a direct predecessor of Brodsky's piece. The key theme of "Safe Conduct" is the relationship between the poet and the powers of state at the onset of Stalin's terror and during the time of radical and catastrophic changes in the whole of society. The title functions as Pasternak's self-defence, an attempt to safeguard himself as a poet, to save and preserve his personal and cultural attachments, including his affiliation to western literature and art. Migration, in turn, puts the role of a writer in a new society to severe proof which Brodsky describes as loss of significance. ${ }^{35}$ As stated by Wanner, a translingual biog-

33 Elizabeth Klosty Beaujour argues that the process of translation is impeded by bilingualism, the use of each language triggering its own mode of writing (Elizabeth Klosty Beaujour. "Bilingualism", in Garland Companion to Vladimir Nabokov, 37-44; "Translation and SelfTranslation". in Garland Companion to Vladimir Nabokov, 7I4-725). According to Klosty Beaujour, translation and auto-translation of Speak, Memory paved the way for Nabokov's later "intrinsically polyglot" Ada (Ibid. 722).

34 Elisabeth Bruss connects her study of the evolution of autobiography to the linguistic theory of the speech act as formulated by John Searle and John Austin. She initiates a discussion of autobiography as illocutory (Searle) or performative (Austin) speech act: Elisabeth Bruss, "L'autobiographie considérée comme acte littéraire”, Poétique I7 (I974): I4-26. Homi K. Bhabba even speaks of the "performative, deforming" transformation of modernity by postcolonial culture: Bhabha, Location of Culture, $24 \mathrm{I}$.

35 Brodsky speaks of the writer's loss of significance: "The democracy into which he has arrived provides him with physical safety but renders him 
raphy is "a radical act of assimilation" ${ }^{36}$ Arguably it is equally an act of self-preservation in a new environment and is a claim of authenticity - and difference - as in Brodsky's "Watermark". In this sense all translingual biographies act as "safe-conducts" passports, so to speak, into adoptive literatures.

Despite not having created its own genres, transcultural literature has its own arsenal of poetic means and an array of shared specific features. It has been re-using certain "favourite" traditional genres (such as autobiography or utopia), transforming them from within.

To conclude the discussion of transcultural poetics, one might add that the notion of poetics can be understood widely as not necessarily limited to textual patterns, but extended to cultural roles and patterns underlying biographical legends. Russian literature has its own transcultural heroes, whose writings and biographies both serve as a compass to writers of younger generations. These are Nabokov and Brodsky, who chronologically demarcate the period of Soviet isolation: Nabokov the beginning and Brodsky the end. The mythology of the writer in Russia, which had cast him as a demiurge at the end of the nineteenth century, and later on as a martyr, also exhibits a third type: that of the writer as unifier of an antagonised world, a crosser of boundaries who breaks free of the double isolation of the Soviet political system and of exile. That is why Nabokov's belated influence on contemporary literature, like Brodsky's, is still on the rise.

\section{Bifurcating Paths: Cosmopolitan or Neo-Vernacular?}

What we see in the writing of the "fourth wave" is a growing flexibility and variation in the choice of which language to use. Mikhail Shishkin lives in Switzerland, but the first publications of a number of his acclaimed novels appeared in Russian and in Russia. At the same time his Montreux-Missolunghi-Astapovo, in the Steps of Byron and Tolstoy (the complete original title in

socially insignificant. And the lack of significance is what no writer, exile or not, can take." (Brodsky, "The Condition we call Exile”, 2).

${ }_{36}$ Wanner, Out of Russia, 5-6. 
German being Montreux - Missolunghi - Astapowo. Auf den Spuren von Byron und Tolstoj: Eine literarische Wanderung vom Genfersee ins Berner Oberland (2002)) was written in Russian, was in part auto-translated and was first published in German. Translation in a wide sense even involves other media: Shishkin's short story "Nabokov's Inkspot" ("Kljaksa Nabokova”, 20I 5 ) was reworked and staged as a play in German in Switzerland. The current situation allows writers to retain their link with Russia and combine it with a cosmopolitan lifestyle.

By contrast, Andreï Makine has taken a different path: as mentioned, he writes exclusively in French. He is a critic of globalism, which he equates with mass culture, and poses as a defender of traditional France from the impact of "egalitarisation" 37 . However, Makine's praise of the spirit of French culture ("francité") does not come from its inside; it is at least in part a viewpoint of an admiring outsider defending French cultural idiocracy. The question about the cultural choices of the upcoming generation of Russian transcultural writers, bilingual children of the third and fourth wave, remains open for the future.

Another question that has not yet been sufficiently addressed in current research concerns how transcultural literature relates to world literature. The conception of world literature as based on the circulation of texts, with loss and acquisition of meaning occurring in the process of re-contextualisation, has entailed the indiscriminate treatment of transcultural writing as a part of this circulation..$^{3}$ An understanding of transcultural literature as world literature has also already been expressed: the question of how to place it remains. ${ }^{39}$ Mads Rosendahl Thomsen has called migrant literature an important "cluster" within world literature and a mode of writing that "changes the way we think about the

37 Makine, Cette France, 65.

${ }^{8}$ David Damrosch defines world literature as "a mode of circulation and reading”. His discussions includes, however, examples from a transcultural Nabokov, his translations of Eugene Onegin and Alice in Wonderland: Damrosch, What is World Literature?, I 57-58.

39 The issue is addressed in Hausbacher, Poetik der Migration, I07-Io; Heidi Rösch, “Migrationsliteratur als Neue Weltliteratur?”, Sprachkunst I (Jg XXXV/2004): 89-I09. 
world"..$^{40}$ Transcultural literature supersedes national literatures, it "performs" cosmopolitanism in reality. This version of cosmopolitanism is neither envisioned as a "concert" of cultures, nor is it an idealised heterotopian "elsewhere": it is the sum of cultural experiences acquired in direct contact. It appears that the circulation of people and the circulation of texts should be regarded as complementary to each other, as two distinctive flows in the accelerated "hypermodern" world.

Today there is a multiplicity of cultural choices. The questions and tensions of transcultural literature - a literature of difference and transition - arise on the path toward assimilation. Transcultural literature is not about effacing, but about embedding differences into new contexts, claiming a place both in the original and in the adopted cultures. Transcultural writing can be regarded as a mediator between national literatures. Biculturalism and multilingualism can no longer be associated with the periphery $;^{4 \mathrm{I}}$ the paradox is that the cultural borders are moving into the centre of contemporary national cultures.

\section{Bibliography}

Appadurai, Arjun. "Disjuncture and Difference in the Global Cultural Economy”.Theory.Culture.Society, I990, http://www.arjunappadurai. org/articles/Appadurai_Disjuncture_and_Difference_in_the_Global_ Cultural_Economy.pdf. Accessed I7 March 2017.

Augé, Marc. Pour une anthropologie des mondes contemporains. Paris: Aubier, I994.

Ausoni, Alain. "En d'autres mots: écriture translingue et autobiographie". In L'Autobiographie entre autres. Écrire la vie aujourd'bui,

$4^{\circ}$ Mads Rosendahl Thomsen, Mapping World Literature: International Canonization and Transnational Literatures (London: Continuum, 2008), 97, 99.

${ }^{4}$ I Boundaries of the the semiosphere are according to Lotman the "hottest spots" for semiotisation processes. Yuri M. Lotman, Universe of the Mind: A Semiotic Theory of Culture (London: Tauris, I990), I36. 
edited by Fabien Arribert-Narce and Alain Ausoni, 63-84. Oxford and Bern: Peter Lang, 20I3.

Bakhtin, Mikhail. "Forms of Time and of the Chronotope in the Novel". The Dialogic Imagination: Four Essays, edited by Michael Holquist, 84-258. Austin: University of Texas Press, 2008.

Bhabha, Homi K. The Location of Culture. New York: Routledge, I994.

"Cultural Diversity and Cultural Differences". Accessed 2 I March 20I7. http://monumenttotransformation.org/atlas-oftransformation/html/c/cultural-diversity/cultural-diversity-andcultural-differences-homi-k-bhabha.html.

Brodsky, Joseph. "The Condition We Call Exile". New York Review of Books, 2 I January I988. Accessed I7 March 20I7. http://www. bisla.sk/english/wp-content/uploads/20 I 5/O I/Joseph-BrodskyThe-Condition-We-Call-Exile.pdf.

Bruss, Elisabeth. "L'autobiographie considérée comme acte littéraire”. Poétique I7 (I974): I4-26.

Damrosch, David. What is World Literature? Princeton and Oxford: Princeton University Press, 2003.

Dostoevsky, Fyodor. “Old People”. A Writer's Diary, vol. I. I873I 876, trans. Kenneth Lantz. With an Introductory Study by Gary Saul Morson. Evanston: Northwestern University Press, I994.

Grayson, Jane. Nabokov Translated: A Comparison of Nabokov's Russian and English Prose. Oxford: Oxford University Press, I977.

Foucault, Michel. "Des espaces autres". 54 Empan (2/2004): I2-I9. Accessed I6 March 20I7. http:// www.cairn.info/revue-empan2004-2-page-I 2.htm.

Gilsenan Nordin, Irene, Hansen, Julie, Zamorano Llena, Carmen, eds. Transcultural Identities in Contemporary Literature. Amsterdam: Rodopi, 20I3.

Groys, Boris. "Zurück aus der Zukunft: Kunst aus Ost und West”. In Zurück aus der Zukunft: osteuropäische Kulturen im Zeitalter des 
Postkommunismus, edited by Boris Groys, Anne von der Heiden, Peter Weibel, 4I9-26. Frankfurt am Main: Suhrkamp, 2005.

Hausbacher, Eva. Poetik der Migration. Transnationale Schreibweisen in der zeitgenössischen russischen Literatur. Tübingen: Stauffenburg, 2009.

Kellman, Steven. The Translingual Imagination. Lincoln: University of Nebraska Press, 2000.

Klosty Beaujour, Elizabeth. Bilingualism". In Garland Companion to Vladimir Nabokov, edited by Vladimir Alexandrov, 37-43. New York: Garland, I995.

. "Translation and Self-Translation". In Garland Companion to Vladimir Nabokov, edited by Vladimir Alexandrov, 7I4-24. New York: Garland, I995.

Lotman, Yuri. Universe of the Mind: A Semiotic Teory of Culture. London: Tauris. I990.

- Culture and Explosion (Semiotics, Communication and Cognition), edited by Marina Grishakova, I66-72. Berlin: De Gruyter Mouton, 2009.

Lotman, Jurii, Uspenskij Boris. "Binary Models in the Dynamics of Russian Culture to the End of the Eighteenth Century". In Jurii Lotman and Boris Uspenskii, The Semiotics of Russian Cultural History. Introduction by Boris Gasparov, edited by Alexander D. Nakhimovsky and Alice Stone Nakhimovsky, 30-67. Ithaca and London: Cornell University Press, I 985.

McConnell, Justine. “Generation Telemachus: Dinaw Mengestu's How to Read the Air". In Ancient Greek Myth in World Fiction since 1989, edited by Justine McConnell and Edith Hall, 225-37. London: Bloomsbury, 2016.

Makine, Andreï. Cette France qu'on oublie d'aimer. Paris: Flammarion, 2006.

Nabokov, Vladimir. Ada or Ardor: A Family Chronicle. New York: Penguin Classics, 20I I. 
Nivat, Georges. "Speak, Memory". In Garland Companion to Vladimir Nabokov, edited by Vladimir Alexandrov, 674-85. New York: Garland, I995.

Rösch, Heidi. “Migrationsliteratur als Neue Weltliteratur?” Sprachkunst I (Jg XXXV/2004): 90-Io9.

Sedakova, Olga. A poetry reading and discussion at the Department of Slavic Languages and Literatures (Stockholm University), 23 April 20I2. Accessed I6 March 20I7. https://www.youtube.com/ watch?v=FrL 7 wp-uwFM.

Seyhan, Azade. Writing Outside the Nation. Princeton: Princeton University Press, 200I.

Thomsen, Mads Rosendahl. Mapping World Literature: International Canonization and Transnational Literatures. London: Continuum, 2008.

Uspensky, Boris. "Europe as Metaphor and Metonymy (in Relation to the History of Russia)". In "Tsar and God" and Other Essays in Russian Cultural Semiotics, Boris Uspensky and Viktor Zhivov, I75-90. Boston: Academic Studies Press, 20 I 2.

Walkowitz, Rebecca. Born Translated: The Contemporary Novel in an Age of World Literature. New York: Columbia University Press, 2015 .

Yoon Sun. "The Postcolonial Novel and Diaspora”. In The Cambridge Companion to the Postcolonial Novel, edited by Ato Quayson. Cambridge: Cambridge University Press, 2015.

Wanner, Adrian. Fictions of a New Translingual Diaspora. Evanston: Northwestern University Press, 20I I.

Yurchak, Alexei. Everything Was Forever, Until It Was No More: The Last Soviet Generation. Princeton: Princeton University Press, 2005 . 